\title{
Alexsander Yandra
}

Faculty of Administrative Science,Universitas Lancang Kuning, Indonesia.

Email: alexsy@unilak.ac.id

\section{Bunga Chintia Utami}

Faculty of Economics and Business, Universitas Riau, Indonesia.

\section{Khuriyatul Husna}

Faculty of Administrative Science, Universitas Lancang Kuning, Indonesia.

Submitted: 6 Oktober 2019, Revised: 27 December 2019, Accepted: 10 January 2020

\begin{abstract}
Alexsander Yandra
is a senior Lecture and researcher at Departement Public Administration, Faculty of Administration Science, Universitas lancang Kuning Pekanbaru. He has publishes many articles in the area of local politics, public policy, and good governance. He is also a secretary of the institute of Research and Community Service since 2017. He graduated in 2009 from renowned university in Sumatera, where its specialist in Political sciences at Andalas University
\end{abstract}

\section{Bunga Chintia Utami \\ is a Lecture in economic development, Faculty of economic and busineness, Universitas Riau. She has good interest in research topic of planning, public policy, and regional economics}

\section{Khuriyatul Husna}

is a Lecture in public administration, Faculty of Administration Science, Universitas Lancang Kuning Pekanbaru. She is also currently $\mathrm{PhD}$ student in Department of Public Policy and Management, Faculty of Social and Political Sciences, Universitas Gadjah Mada. She has good interest in research topic of public policy, governance and policy network.

Policy \& Governance Review ISSN 2580-4820

Vol. 4, Issue 3, pp. 40-54 DOI: https://doi.org/10.30589/pgr. v4i1.172

\section{Distortion of Government Policy Orientation in Public-Private Partnership (PPP)}

\begin{abstract}
This study examines the issue of Public-Private Partnership (PPP) policy discrepancies in reducing waste management and the occurrence of distortion of disagreement between the city's government and the private sector in interpreting the contents and the scope of the policy influenced by the interests of various stakeholders, the private sector and daily workers. This study uses a qualitative approach on the results of ethical and emic data, discussing the content of short-term project-oriented policies, which are limited to the transport of waste to cause long-term policy orientation anomalies in the trash business, thus impacting the accumulation of waste on the road, termination of unilateral contracts and demonstrations by daily workers. For this reason, PPP policy implementation shows high interest but has a low contribution to the community in Pekanbaru.
\end{abstract}

\section{Keywords:}

distortion; policy orientation; public-private partnership

\section{Introduction}

Public-Private Partnership (PPP) is not only used as a policy brand but also as a political practice in daily life in many countries, particularly in developing countries (Klijn, 2010). There are undoubtedly different motives and purposes for each country to apply PPP. Reasons for applying PPP include attracting private investment, more value for many (VfM), promoting innovation, and better decision-making and project management (Koppenjan, 2008). Parente (2006) in his research mentions several countries and the reasons they chose a PublicPrivate Partnership (PPP): The United States aims to improve operational efficiency, the UK 
aims to increase competition, South Korea aims to access and develop new technologies, India aims to create employment opportunities, South Africa aims to open investment, and the Philippines, as an ASEAN country, aims to create transparency in the procurement of goods and services. PPP policy is considered as a way out of existing development problems. However, according to Bindal (2014), PPP policy is not a solution but a new problem faced by the government. The practice of the problem even arises when the initial stage of the policy is carried out, such as designing a contract between the government and a problematic partner, to unrealistic expectations of the PPP policy itself (Sharma, Bindal, \& Cantt, 2014).

Indonesia is one country that adopted PPP policy to deal with problems in different fields, one of which is paid a heavy focus is about waste management. The government regulates the pattern of the partnership between the government and the private sector through Presidential Regulation No. 67/2005. Law No. 18/2008 concerning waste management was made at the central level as a legal umbrella so that it could be written and implemented by each district or city Regional Government by issuing a Regional Regulation or Peraturan Daerah (Perda) to adjust to the needs and conditions of existing regions. The problem of waste in various parts of Indonesia is partial, which could not equate with each other in its settlement. Another problem is the conventional method of stable waste settlement. Thus, destructive methods are still visible.

The reality has become an indication that the problems in the city of Pekanbaru that spanned the last decade illustrate the increase in the volume of waste from year to year. In addition to this, an increase in the economic activities of the community also raises the level of waste disposal, which is increasingly higher than the citizens so that expectations of the government's role in waste management are essential. Pekanbaru is one of the cities in Riau Province which issued Regulation
No. 8/2014 concerning waste management. This regulation appears as an effort to overcome the problem of waste management.

Based on the increase in the volume of waste annually, Pekanbaru City Government through the Department of Hygiene (DKP) creates a waste management policy with the partnership system, implementing it in eight districts of twelve districts in municipalities and Pekanbaru. The districts that are involved in the partnership include Marpoyan Damai, Senapelan, Sukajadi, Tampan, Sail, Pekanbaru, Payung Sekaki. In total, there are partnerships with fifty-three parties (private), and this paper looks at PT. Multi Inti Guna (MIG). This is because to follow Article 11 of 2014, which states that the Government of Pekanbaru should involve third parties in the waste management department, PT. MIG is the winner of the auction using the 2015 APBD with a contract value of 53 billion Rupiahs.

However, problems in waste management arose when in April 2016. The salaries of employees under PT. MIG were apparently unaddressed, as they were reportedly unpaid by the PT. MIG. As a result, the Pekanbaru Government, through the Department of Hygiene and Landscaping (DKP) terminated the contract with PT. MIG with letter number 232/DKP/VI/2016 on June 15, 2016. As a result of the termination, garbage piled up in eight (8) areas that became the contract area. Some issues related to the issue of waste tonnage amount conducted by PT. Sucofindo, which stated that the amount of waste produced by Pekanbaru City was 610 tonnes/day. But according to PT. MIG, the amount of waste is much smaller than the amount stated. Consequently, PT. MIG suffered some losses. So, in this case, it is necessary to look back at the volume/amount of waste that is the object of this policy-the PPP contract between Pekanbaru City Government and PT. MIG.

The Pekanbaru Government considers that PT. MIG has misused the contract, whereas the PT. MIG considers that Pekanbaru Government 
has violated the partnership pattern policy by unilaterally terminating it. The polemic is at the root of the problem of policy failures whose effects occur in the accumulation of garbage at the Pekanbaru road, especially in eight sub-districts and the demonstration of THL. It is necessary to conduct a study related to PPP policies carried out by the Pekanbaru Government with PT. MIG regarding the waste management contract. The formulation of the problem focuses on the implementation of PPP policy Local Regulation No. 8/2014 between the Government of Pekanbaru and PT. MIG, and is especially interested in finding out the factors of failure of the Public-Private Partnership (PPP) policy between the Pekanbaru Government and PT. MIG in waste management. A theoretical approach based on Merilee S. Grindle's model is used to sharpen the analysis of this study and explain that policy implementation divided into two variables, namely content and implementation contexts.

\section{Literature Review}

\section{Public-Private Partnership}

Klijn and Teisman (2003) defined PPP as, "More or less sustainable cooperation between public and private actors in which joint products and/or services developed and in which risks, costs and profits are shared" (Klijn, 2010). This particular case of PPP happened in a waste project that focuses on the problems on the regulation, contract, decision-making and performance. These are some topics that often occur in PPP researches. Some researchers have made a mapping of PPP researches, which results in some topics and sub-topics often studied in research.

\section{Public-Private Partnership (PPP) As a Hybrid Perspective}

PPP is a hybrid idea of New Public Management (NPM) and the government's perspectives in public administration (Klijn, 2010). The NPM and government regard PPP as a public administration practice and context. Klijn (2010) argued that:

"The NPM view tells us to use performance indicators, to organize the PPP's at arm's length and its strong emphasis on efficiency and market mechanism. It is the world where the main argument for PPP's is that they are separate organizations (that is at a distance of the confusing world of politics) that can

Table 1.

Topics Mapping of Researches on Public-Private Partnership (PPP)

\begin{tabular}{|c|c|c|}
\hline Authors & Periods & Topics \\
\hline (Ke, Wang, Chan, \& Cheung, 2009) & $1998-2008$ & $\begin{array}{l}\text { Investment environment, procurement, economic viability, } \\
\text { financial package, risk management, governance issues, and } \\
\text { integration research }\end{array}$ \\
\hline $\begin{array}{l}\text { (Marsilio, Cappellaro, \& } \\
\text { Cuccurullo, 2011) }\end{array}$ & 1990-2010 & $\begin{array}{l}\text { Governmental and intergovernmental organizations (IGOs), } \\
\text { public administration and public policy academics, scholars } \\
\text { studying transaction cost and contract theory, and scholars } \\
\text { studying strategy and alliance/network theory }\end{array}$ \\
\hline (Andon, 2012) & Up des 2010 & $\begin{array}{l}\text { The nature of and rationale for PPPs, processes and } \\
\text { procedures encouraging the decision-making for } \\
\text { undertaking PPPS, processes and procedures for export } \\
\text { evaluations of PPPs, merit and worth of PPPs, and PPP } \\
\text { regulation and guidance }\end{array}$ \\
\hline $\begin{array}{l}\text { (De Castro E Silva Neto, Cruz, } \\
\text { Rodrigues, \& Silva, 2016) }\end{array}$ & & $\begin{array}{l}\text { Contract performance, qualitative costs and benefits, } \\
\text { contract design and risk sharing, political and institutional } \\
\text { issues, and tests on value for money }\end{array}$ \\
\hline (Chen, Daito, \& Gifford, 2016) & & $\begin{array}{l}\text { Performance, contract, risk, value for money, and } \\
\text { institutional factors }\end{array}$ \\
\hline
\end{tabular}

Source: Cui, Liu, Hope, \& Wang, 2018. 
go on implementing urban regeneration schemes, attracting private money and getting "the job done." It is the promise of efficient bodies run in an own managerial way delivering excellent outcomes for less money. In the world of the governance argument, PPP's are cooperative bodies where the best from public and private was used, creating innovative solutions by matching knowledge and expertise, using horizontal coordination mechanisms, that is various kind of network management strategies, to improve coordination and enhance valuable outcomes" (Klijn, 2010)

Both perspectives are different in each achieving goal. The NPM perspective assumes that the government should be more focused on the formulation of public policy while the implementation process delegated to the private or non-profit sectors of the organization for efficiency. Otherwise, based on the governance perspective, we realize that the government cannot handle the process of a policy to achieve its goal as a single actor only. There should be coordination and collaboration with a private or non-profit organization (NGO). Hence, PPP could expect a solution in which both goals could be achieved at the same time. There is actually a motive that becomes a dominant reason to apply PPP, which is "better decision making" (Koppenjan, 2008). The NPM perspective emphasizes that private or non-profit organizations should handle the policy implementation process.

\section{The Application of the PPP Model in Waste Management}

Types of infrastructure projects that could apply the PPP model include transportation (seaports, rivers, air, rail networks, and train stations), roads (tolls and toll bridges), irrigation (raw water carriers), drinking water (water extraction buildings) raw materials, transmission networks, distribution networks, drinking water (treatment plants), wastewater and waste facilities (transports and disposal sites), telecommunications, electricity, oil and gas.
Management is one of the infrastructure projects that apply the PPP model in many countries. Wang et al. (2019) stated that the application of the PPP model in waste management produced two benefits at the same time, namely reducing the pressure of local governments, increasing efficiency and reducing pollution during the disposal process (Wang et al., 2019).

The application of the PPP model has different impacts in its application in various countries. Some research results which applied the PPP pattern in waste management mentioned several success and failure factors in its application. Like China, in Asian countries, China is a wasteproducing country whose growth is 5\% higher than other Asian countries (Mian et al., 2017 as cited in Wang et al., 2019). In China, garbage services are dominated by household waste (Zhang, Tan, \& Gersberg, 2010). In the results of his research, Wang et al., (2019) described the low signing rate and secondary pollution as risks faced by China in handling waste using the PPP model. The results of his research also show that the low price tender is dangerous for the continued development of the PPP model in waste services as well as reducing the welfare of the community.

Contrasted to China, research conducted by Awortwi (2004) in three cities in Ghana states that the success of waste management using the PPP model is determined by governance capability. In the Czech Republic, the PPP model in waste management causes high costs or is more expensive than other forms of service.

The best model for solid waste to the new capital city AMARAVATHI is automated plastic separation module. The estimated cost is $26,000,000$ for implementing this project, and the land required for control and management of the municipal solid waste in cities is $4500 \mathrm{sqm}$. When applied, this model could reduce the maintenance cost for the handling sectors and generate revenue by automating the plastic separation module (Sai et al., 2017). 
According to Meidiana \& Gamse (2010), the practice of handling waste in Indonesia is still not running efficiently due to the inadequacy of the law regarding waste management. All the problems faced by many countries in handling waste using the PPP model must be a record that should be corrected, especially in terms of the policy so that the excellent service provided to the public could realize optimally.

The other research seeks waste management in Semarang through cooperation activities and partnership, as stated in Local Government Regulation No. 6 in 2012 about Waste Management chapter IX. The relationship between Investment \& One-Door Integrated Service Office with PT. Narpati less running smoothly because of PT. Narpati did not fulfil its obligations to pay contributions (Setyawati, 2018). As for the aspects that are considered still not appropriate and not going well, the Semarang Government and PT. Narpati implemented a cooperation policy in waste management in Jatibarang TPA regarding the accuracy of the policy and the process which were not quite optimal, despite the targeting and environmental accuracy of the implementation going well.

Naharudin's study shows theimplementation of PPP between the Makassar government and PT. Gikoko Kogyo Indonesia, and considers the outputs and outcomes of the partnership that exists. The implementation of the partnership carried out only focused on the LFG project, while the implementation of the community empowerment program and the development of solid waste management as stipulated in the MOA was not yet applied because of constraints on royalties from CER payments. Then the sanitary landfill method as environmentally friendly waste management cannot be managed in this partnership. This partnership also provides benefits to the local community in the form of a reduction in the smell of garbage and lighting lamps in the landfill, which provide ease of nighttime activity (Nahruddin, 2016).
Kurniawan (2016) in his research findings, concludes that using the BOT model between Surabaya City Sanitation and Parks Agency with PT. Sumber Organik (SO) in waste management at the Benowo landfill runs well. But some things still need attention. PT. SO don't do consultation public, feasibility study and review of risks in advance. In partnership, it uses the Build Operate Transfer (BOT) cooperation models. Waste management in the Benowo landfill along with infrastructure development is carried out by PT. SO based on an agreed decision with a concession period of 20 years. After the concession period ends, PT. SO is obliged to return all assets and operations in TPA Benowo to DKP (Kurniawan, 2016).

The problem of implementing PPP policies in various regions is inseparable from the lack of understanding of the implementation of the policy content, including the application in Pekanbaru in waste management by involving the private sector as a third party which has an impact on the emergence of PPP policy distortions, namely termination of unilateral contracts on the grounds of unclear contents of the policy contract between Pekanbaru government and PT. MIG.

\section{Methods}

The qualitative research method used in this discussion is based on Cresswell's method, which is used as a method to explore and understand the meaning of individuals or groups that are thought to originate from social and humanitarian problems. The sources and types of data in this research is primary data from informants that have fulfilled specific relevance criteria related with PPP, and secondary data obtained from literature and documentation associated with the PPP Policy Regulation No. 8 of 2014, print media, or electronic media related to PPP policies such as contract documents and photographs of garbage piles around 2016. Data collection was carried out with the process of observation, oral studies, and measurable in-depth interviews. The analysis 
of qualitative data is done using the techniques proposed by Miles and Huberman, namely data reduction, data presentation and conclusion drawing (Yandra et al., 2018). This process takes place continuously throughout the study, even before the data is collected. When sharpening the analysis of research data, ethical information is needed, namely the views of researchers based on existing theories and concepts, and the emic information is the view of the informant.

\section{Public-Private Partnership Policy Orientation in Pekanbaru City in Waste Management}

Waste management policy through a partnership pattern could be interpreted as an effort involves the role of the private sector in resolving waste issues, as well as fostering community behaviour to reduce waste production. The waste handling process starts with the collection process. Selection to the final disposal site (TPA) requires a different time so that space is needed to accommodate the waste in each process. The type and composition of waste are strongly influenced by the level of community culture and its natural conditions. The more advanced the level of community culture, the more complex the sources and types of waste encountered. A higher the economic status of a population, the greater the generation of waste. PPP policy orientation should be able to reverse the paradigm into a higher level of the population's economy. Through PPP Policy Regional Regulation No. 8/2014, Public expectations regarding waste problems in the city of Pekanbaru can be resolved through the waste management process as well as educating the community about reducing waste consumption.

On the contrary, the PPP policy has not been able to reduce waste generated by changing people's behaviour and raising public awareness. This is because the limitations of waste disposal services make some shops, workshops, households, hotels, offices and other sources of waste in Pekanbaru City carry out garbage disposal in inappropriate places such as rivers, vacant lots, and the roadside, etc. The volume of waste is enormous and did not match the capacity of the landfills as it exceeds the capacity of the final disposal sites (TPA).

The Pekanbaru City Government should not only be involved in the process of transporting the waste, but also in the process of recycling and reducing waste so that it can affect the economic value of the community. With the use of technology, the policy orientation changes the waste management into a business of garbage (waste business), as this kind of move has become a strategic choice in dealing with the issue of waste. Still, it is a participatory need to build public awareness through education waste; it can also be a way to build a new paradigm of society. The direction of PPP's policy is strategic if it contains various innovations in the prevention of waste. The efficiency of the policy will be felt by the Government, Private Parties and the public, although the overlap of the policy's focus with the policy's locus was a somewhat tedious issue in the implementation of PPP policy.

\section{Content Distortion Orientation (Content) PPP Policy}

Policy failure could be caused due to the loss of direction of interest policy, poor planning or poor implementation. Managing policy issues with the partnership garbage Public-Private Partnership (PPP) is terrible and not only causes losses materially but also non-materially, and even leads to declining public confidence in the government. Termination of the contract between the Government of Pekanbaru and PT. MIG became the climax of the failure of the PPP policy to be implemented. Government policy No. 54/2010 explains the termination contract must be preceded with a first, second, and third warming, with each action followed with a meeting discussing the reasons. The last process is the test case that determines whether a provider passes 
in sustainability contract. PT. MIG is concerned about the absence of these stages carried out by the Government of Pekanbaru. The case describes the content (content). PPP's policy will be on various interests and influences that exist in the scope of the policy.

\section{Affected Interests}

PPP policy is strongly influenced by the interests of nature's sector and non-sector and correlated to the acceleration or deceleration of the policy to be implemented. Actors with interest in the existence of Regional Regulation No. 8 of 2014 are the public, the private sector and the government. The community as an interest group divided into the policy recipient community and the community as the policy implementer. The interest of the community in receiving policy is the importance of receiving public services and a clean and healthy environment. While the community was implementing the policy, the people who work as Officers Daily Officers (PHL) were getting wage compensation, as stated in the employment agreement. The total PHL of Pekanbaru City DKP has changed since the emergence of waste management regulation. The local regulation resulted in changes in the waste management system, which previously involved sub-districts with a sub-district of 354 people in the field of waste management in 12 sub-districts to switch to THL DKP in Pekanbaru City. 16 November 2015 waste transportation cooperation with PT. MIG was applied so that 354 people transferred to PT. MIG's resources. But due to the termination of the contract in June 2016, THL returned to being part of the DKP.

The private sector as an interested actor includes private parties who participate in the auction of garbage transport, the private sector as the auctioneer and the private sector as the recipient of the results of the policy of transporting garbage in the commercial area. The government as an interested actor includes the sub-district government, the Department of Sanitation and
Parks and the Market Service. Letter of Solid Waste Transport Service Agreement No. 25/KONT-DKP/ Persampahan/XI/2015 dated November 3, 2015, first addendum number 25.a/ADD.1/KONT-DKP/ Persampahan/XII/2015 dated December 3, 2015, concerning Transport Service Agreement Waste. The addendum is an additional clause or article in the contract or agreement.

A good policy is a policy that can accommodate the interests of various parties without harming the interests of other parties. The interests of one party may be of benefit to the interests of the other party, or the interests of one party may reduce the benefit of the other party. So if one interest is fulfilled, then it is directly proportional to the accommodation of the other party's interests or just the opposite. If the interests of one party are fulfilled, then the interests of the other party will not be fulfilled or only slightly fulfilled.

In the PPP waste management program in Pekanbaru, the interests between the community, government and the private sector (in this case, PT. MIG) are directly proportional to each other. This means that when the interests of one party are fulfilled with this policy, the interests of the other party would also be accommodated. For example, the community's interest in PPP waste management is the interest in getting a clean and comfortable environment. The interests of PT. MIG is to benefit from the implementation of waste management activities in the form of the amount of garbage collection and payment of activities from the city government of Pekanbaru, while the interests of the City Government of Pekanbaru is to get the public to believe that Pekanbaru is a clean and healthy city. The three interrelated interests are not contradictory, meaning that with the existence of PPP policies, all interests of the various parties are accommodated because they are mutually beneficial to each other. However, if one of the interests did not fulfil, the other interests would be disturbed. 
When the government does not fulfil the company's interests due to obstruction of the disbursement process that has implications for the payment of PHL workers' wages, the community's interest in getting a clean and comfortable environment is not fulfiled because PHL is on strike. This also has an impact on the interests of the government to gain public trust as a service provider and to lose the trust of government partners. PT. MIG and the community sued the government.

Office of Sanitation and Landscaping Service number 232/DKP/VI/2016 dated June 15, 2016, regarding the termination of the cooperation contract for waste transportation. As a result of the termination of employment, PT. MIG filed a lawsuit with Defendant 1, Head of the cleaning and gardening service and Defendant 2, namely Edwin Supradana S.T., M.T. Termination of employment interferes with the interests of PT. MIG as the executor of the policy. PT. MIG won this lawsuit so that the DKP must pay the remaining payment for the work that is still insured.

\section{Benefit Type Policy}

The cooperation contract between DKP and PT. MIG should run from November 2015 to December 2016. This collaboration is planned as a public-private partnership example that is multi-year in nature. The benefits provided by the collaboration are waste transport services to the Final Disposal Site (TPA) in the Muara Fajar village. This collaboration should provide benefits for PT. MIG in the form of payment of services of eighty-five thousand for every ton of waste transported. This is different from the one implemented in 2018. The system of cooperation in waste transportation with third parties does not use a system of fines for the private sector if the amount of waste is not in accordance with the target. Excess transport services from the zone to the landfill, specifically for two hundred thousand waste, will be paid that are insured by the government in the following year.
Benefits are also provided in the form of services. The expected service is in the form of an increase in the trash transported from the TPS to TPA. In 2016 the amount of garbage transported decreased compared to the previous year. The average amount of garbage transported in 2016 is 332.54 tons/day, with a total yearly waste of $121,707.84$ tons.

Table 2.

Waste generation recapitulation

\begin{tabular}{lc}
\hline Year & Total (Tons) \\
\hline 2013 & $133,500.26$ \\
2014 & $144,532.70$ \\
2015 & $148,819.75$ \\
2016 & $121,707.84$ \\
2017 & $132,232.49$ \\
\hline
\end{tabular}

Source: DKP, 2018

Facilities or infrastructure in the Muara Fajar Landfill, when compared to the annual landfill recapitulation, should not be ideal because the volume of waste that is increasing every year and the infrastructure and quantity and quality are irrelevant. The accumulation of waste outside of control often happens when the implementation of the policy is not oriented to waste management or waste business as contained in the contents of the policy.

\section{The expected degree of change}

The contract of cooperation between the Government and PT. MIG in waste management wanted to change the conditions of waste management, especially in waste processing and garbage transportation. The target set in the cooperation contract is that PT. MIG must lift as much as 610 tons of garbage per day-when the transported waste is only 400 tons per day. According to PT. MIG, this happened because the PT. MIG had limited inadequate infrastructure. The Pekanbaru City Government hopes that cooperation can create efficiency and effectiveness of garbage transportation. Still, the conditions 
in the field show various problems that result in constraints in the implementation of waste transportation and garbage collection. The government, when providing projects to the private sector, must pay attention to various aspects that must then be agreed upon. In this context, an error would occur if the government has no firm control in giving a warning to PT. MIG if it does not operate according to the agreement. But on the contrary, the government experiences failure due to the inability to implement a public-private partnership policy in waste management due to delays in providing costs for the implementation of policies as contained in this policy contract. If Pekanbaru city government is not ready for the PPP policy it makes, it is necessary to maximize the potential internal sources related to the facilities and infrastructure it has, so that the problem of fleet limitations in the process of transporting waste is not at the root of policy failure.

DKP references in waste management to East Kalimantan, Jakarta, and Surabaya. This is due to excellence in areas such as East Kalimantan being the best eastern region in landfill management by converting waste into energy. Jakarta also serves as a reference because of its success with the concept of unification of waste and water that they distributed, although said concept is challenging to implement in Pekanbaru because only $5 \%$ of the population uses PDAMs. Meanwhile, Surabaya is a reference because it is the best area for implementing the $3 \mathrm{R}$ concept, namely reduce, reuse and recycle. There needs to be a new model in waste management that involves the private sector as the party responsible for waste problems. The policy is not only related to the transportation process from the pile to the disposal site, but the policy also provides an opportunity to make waste a new business (business of garbage) and to make garbage no longer seem harmful, but rather make garbage look like it has economic value to society. This new model should be pursued by the government by involving the role of the private sector and society in a participatory, directed and sustainable manner. The value of this change is expected from PPP policy, that is the change in business governance oriented to waste will be a trend in reducing various waste problems in Pekanbaru.

The fundamental change desired from the PPP Policy is a change in the lifestyle of the community. The agreed PPP policy for waste transportation is transportation at a specific time so that it requires a change in the pattern of the community in waste management because the waste transported by PT. MIG is only carried out according to a predetermined schedule and place.

Desired changes from this policy can be achieved if there is a joint effort from various parties involved. Changes in community behaviour in disposing of garbage at the right time and place of transportation can be a solution to the limitations of the available transportation/fleet by means of efficient transportation time. However, to be able to change people's behaviour is just an appeal. The government must have its program to form patterns of community behaviour in disposing of waste.

\section{Decision-Making Position}

The position of the Sanitation and Landscaping Office as the decision-maker to implement the PPP concept as outlined in the agreement letter between the Service and PT MIG is based on the official authority, the Sanitation and Landscaping Service as stipulated in the Pekanbaru City Regulation No. 8/2008 concerning Arrangement Formation Organization, Position and Main Tasks of Offices in the Pekanbaru City Government. In Chapter XV of the Regional Regulation, the Department of Hygiene and Landscaping of the Pekanbaru has the task of carrying out part of the Regional Government Affairs in the Field of Hygiene and Landscaping.

DKP as the party has given the authority for PPP decision makers', which was revealed in technical policy in the form of waste transportation 
cooperation activities. Therefore, the government, through the DKP, can describe the policy demands by considering various aspects contained in the policy charge, such as economic aspects, citizen education, and rewards and punishment. Besides, through the DKP and PT. MIG should synergize to be integrated into an offsetting role. This decision is accompanied by preparing the completeness of the tender document. When the tender document has been prepared, then it is submitted on ULP. Even though the auction process has been carried out correctly, the advantages and disadvantages need to be known by the government in the appointment of winners not to be halted in the future.

The PPP policy should place the position between the Pekanbaru City Government/DKP, and PT. MIG is the same and consultative. The waste management master plan contains the amount of waste and the point of waste in the city of Pekanbaru. PT. MIG carries out the technical implementation of waste management. The same position should encourage two-way interaction between the two in implementing PPP policy.

It is different if the position of policymakers is not PPP. For example, policies that hand over $100 \%$ implementation to the implementing activities. So the position of the decision-maker is on the employer. The desired PPP concept is a partnership between the government and the private sector.

The position of the decision-making position in PPP is a joint decision so that if a problem occurs, such as a buildup of waste, the decision taken is not within PT. MIG or the DKP, but is in coordination between the two. The conditions that occur are decisions taken when there are obstacles in the field made by DKP by stopping payments and terminating contracts or decisions taken by PT. MIG in the form of terminating payment of THL wages. Both decisions made by each of them actually cause PPP policies not to be implemented because both parties show their respective strengths in a decision.

\section{Program Implementer}

In the implementation of waste management in Pekanbaru, there was a change from 2016 to 2018, where at present it is divided into three zoning areas: the private sector handles zones 1 and 2 , and the government handles zone 3 . The zoning division is as follows:

1. Zone 1 includes Marpoyan Damai, Tampan, Pekanbaru, Payung Sekaki.

2. Zone 2 includes Senapelan, Sukajadi, Sail, Lima Puluh, Tenayan Raya, and Bukit Raya.

3. Zone 3 covers other areas managed by the city government.

Zone 2 is carried out by PT. Samhana Indah with a target of 350 tons of waste. The auction process is carried out multi-years with a budget of 177 billion for two zones. This is different from the implementation of the collaboration program conducted with PT. MIG in 2016. The payment system made by the government to PT. MIG is to adjust the amount of waste transported by PT. MIG. It seems that there is no definite measure of the previous policy so that it creates confusion in understanding the policy content; this is what causes some of the daily freelancers to get no wages as they deserve.

The failure of the previous policy was also inseparable from the improper implementation of program factors in building understanding in the policy contract. Pekanbaru City Government and PT. MIG tend to blame each other when policies are not implemented properly. The policy is more project-oriented than about alleviating waste problems. Program implementers also do not have detailed data and information related to policy issues so that data and information contained in the contract between the government of Pekanbaru and PT. MIG is unrealistic, with the volume of garbage conditions in Pekanbaru increasing every day. Program implementers assess waste issues from one viewpoint so that the solution offered is only the transportation process. 
The waste problem should be seen from the many perspectives so that there are other options that need to be done in handling waste in the city of Pekanbaru.

\section{Resources involved}

Regarding the resources, DKP engaged in cooperation with PT. MIG on as many as 1159 THL Handling Section. The final waste management process in 2016 was divided into THL Sweeping, THL garbage transport, collector foreman and clerk levy. All THL involved play a role in the waste transport process, but they do not play a role in the processing and recycling of waste. The details of the THL are as follows:

Table 3.

Total THL of Final Waste Section and Impression in 2016

\begin{tabular}{lc}
\hline Type of work & Amount \\
\hline Sweeping the Protocol & 314 \\
Sweeping 12 Subdistricts & 324 \\
Garbage Transportation & 496 \\
Foreman & 13 \\
Retribution Collection Officer & 12 \\
TOTAL & 1159 \\
\hline
\end{tabular}

Source: DKP, 2018

In addition to human resources, the resources used are in the form of infrastructures, such as a cleaning fleet, landfill, compost and workshops. The cleaning fleet managed by DKP is made up of 17 pick-up units, 49 dump trucks, 2 Fuso units and 1 road sweeper unit. The TPA fleet is made up of 2 Excavator units, 1 Bulldozer D6 CAT Unit, and 1 Bulldozer D5 CAT Unit. The number of fleets owned by DKP is considered not proportional to the amount of waste available. PT MIG's Transport fleet is made up of 63 truck units to transport all the garbage scattered in eight subdistricts within Pekanbaru.

PT. MIG was overwhelmed in the process of transporting garbage as it was constrained by the THL transport experiencing trouble in finding the garbage's locations. As a result, the performance was not optimal in achieving the target. The fleet was limited to achieving the 610 tons target as stated in the contract. Based on data from the Department of Hygiene and Landscaping of the City of Pekanbaru, it is known that PT. MIG has the task of transporting garbage in eight sub-districts, namely Tampan, Payung Sekaki, Sukajadi, Marpoyan Damai, Pekanbaru, Sail, Lima Puluh, and Senapelan.

It is also in PPP's policy to carefully review the resources involved in the process of transporting the waste, not only from the social sector but also from the facilities and infrastructure. These two elements of resources are very influential in the success of this PPP policy, which can be implemented following policy targets and objectives. But on the contrary, both of these resources have not been able to meet public expectations. Since human resources are involved, most of the casual daily workers do not have the competence to process and recycle waste for other needs. The facilities and infrastructure resources are also limited to the garbage collection fleet, though this is not seen from the data of the city government and PT. MIG who apparently boasted modern waste processing equipment.

Also, the change from the linear system to the zoning will provide convenience to the waste processing and transport process in 2018. However, this change is still limited to the process of transporting waste from the dumping site of the Final Waste Disposal Site. If the system change is not integrated with technology, then the system that is run still looks conventional and is limited to pattern changes. However, the practice is not much different than before. The Pekanbaru City Government also needs to pay attention to the use of third parties as partners in the waste treatment process. Worrying about changes from PT. MIG to PT. Samhana in the processing of waste only eliminates the previous error record, and it is better to consider also the aspects of commodity processing of waste. The 
process of separation of organic and non-organic garbage is also necessary to have information in daily volume, because of previous data from all the trash accumulated only in a project to third parties. This process will facilitate third parties in reducing waste processing or recycling to add economic value. In addition, other efforts are also needed by the government in changing the paradigm of the community with the education of waste processing and stockpiling.

\section{Distortion of PPP Policy Context for Waste Management in Pekanbaru City}

1. The power, interests and strategies of the actors involved

The public interest in obtaining a clean and comfortable environment is affected by the implementation of PPP between the government and PT. MIG. PT. MIG handles waste management in eight sub-districts, namely Marpoyan Damai, Senapelan, Sukajadi, Tampan, Sail, Pekanbaru, Payung Sekaki, and Lima Puluh. The community from eight sub-districts filed a lawsuit through the Legal Aid Institute. The community feels disadvantaged by the violation of Law No. 18 of 2008 concerning Waste Management. The lawsuit filed for material and non-material losses amounted to 53 billion to each party, both the government and PT. MIG. The latter also plays a role as a party of interest. The contract value between PT. MIG and the Pekanbaru City Government of 51 billion is not paid in whole but gradually. By June 2016, PT. MIG had received 9.7 billion payments in the period of work of half a year when the actual amount should have been only two billion. This is apparently due to regional budgeting conditions that were not yet on time and constrained by other priority funding, indicating that the financing of PT. MIG was not done properly.

However, delays in payments cannot be received by PT. MIG, which has an impact on the late payment of Lepa Daily Staff (THL). The delay in paying THL honorarium caused a strike carried out by THL and impacted the accumulation of waste in various TPS points and unilateral termination of cooperation by DKP. PT. MIG has filed a lawsuit for termination of unilateral cooperation and won compensation of IDR 12,771,343,138 against DKP.

\section{Characteristics of Institutions and Rulers}

The understanding between PT. MIG and DKP at the beginning regarding the amount of waste that must be met for 610 tons were not in line with the final process of implementing the cooperation. PT. MIG filed an objection to the amount of waste per day when the conditions in the field were not met and filed a lawsuit against the feasibility study conducted by DKP, which were not deemed as the actual conditions. Before this happens, PT. MIG must also conduct a separate assessment to find the actual amount of waste per day, or it should be before the contract is determined. There is a joint calculation of the daily waste target. The reality shows that the particular preference of PT. MIG is more to the unmeasured actions without examining more closely the real volume of waste per year, while DKP prefers its characteristics to top-down efforts by streamlining work to third parties without being able to design contracts effectively.

\section{Compliance and implementing responsiveness \\ DKP and PT. MIG's compliance with the} implementation of cooperation is considered to be less than optimal. Both parties are considered to be less competitive in carrying out their respective obligations. The government made late payments and PT. MIG did not meet the contract target for the amount of waste per day. Various problems arise due to the termination of the contract. Compliance of both parties on the termination of the contract is under the mandate of Presidential Regulation No. 4 of 2015. As a result of the termination, PT. 
MIG had to complete the THL payment according to the work that was not paid and the government, through DKP, had to take over the THL payment which has actually been terminated by PT. MIG.

The government's response, according to the recent Pekanbaru Mingguan issue, is that the cooperation contract did not run correctly, particularly regarding the diversion of budgets and human resources of four districts in the city of Pekanbaru. The transfer aims to reduce the workload of waste transportation that should be borne by the DKP. The limitations of DKP transport facilities assisted with transport fleets from Sail, Rumbai, Rumbai Pesisir, and Tenayan sub-districts. At the beginning of the transition, the implementation of the policy back to DKP used 33 garbage transport fleets and was assisted by the Cipta Karya and Bina Marga fleet.

\section{Results and Discussion}

Orientation implementation of the PublicPrivate Partnership (PPP) policy Local Government No. 8/2014 between Pekanbaru Government and PT. MIG in waste management is considered to be carried out for a short period, but not in accordance with a long-term agreement or contract. One of the contract characteristics of PPP that becomes standard for the research done by Klijn and Koppenjan (2016) states that long term- characters of a contract period do not influence the partnership performance. Alongside government and private consortium, there is complex actors network that is participated, and its coordination is not ruled by contract. Actor networks that are involved in a private consortium are complicated and include contractor, bank, consultant and operator. Although DBFMO's contract is integrated, it may be that behind the reality screen of this consortium, the contract is separated because that relation is ruled, again, by traditional means.

Klijn and Koppenjan stated that "contracts are probably a necessary or at least an important condition but not a sufficient condition" (Klijn
\& Koppenjan, 2016). PPP contract cannot be regulated by its commitment only. Other complex factors can make the partnership run well, such as interaction quality, management activity, and trust.

Contract mostly does not rule actors network who are explicitly involved (Klijn \& Koppenjan, 2016). By looking at the private sector only, the actors involved have already been complicated and complex, such as bank, consultant, developer and others.

The implementation of PPP policy was halted due to the unilateral termination of the contract by the Pekanbaru City Sanitation and Landscaping Service. Some of the factors that influence implementation failure are the content (content) of the policy, especially in several aspects. The interest of the community as the recipient of the system is considered not fulfilled. It can be seen from several sub-districts which are deemed to have garbage points. 354 THL interests as the implementer of the garbage transporter are not achieved, so THL conducts demonstrations and strikes. When a matrix of stakeholder interests is analyzed, it is seen that the benefits of the recipient community in handling waste policies are in of high importance and profound influence. Handling that must be done for stakeholders with high importance and low influence is communication. At the time of the accumulation of garbage, the government should communicate with the community in the implementation or overcoming the obstacles when the cooperation is not working correctly.

The interests of the cleaning staff of the freelance daily workers are in a condition of high importance and strong influence. The government must be able to build relationships when implementing the concept of public-private partnership. This is because stakeholders with high importance and high influence conditions must be considered as sources of the emergence of vulnerability in policy implementation. 


\section{Conclusion}

The distortion happened because some factors of policy content and context were not implemented appropriately. Distortion comes from PT. MIG as the winner of the project of waste management in Pekanbaru, who broke the agreement. It could be seen from the problem of waste deportation, the lack of armada number which is less than what has been agreed in the partnership agreement, the delay of THL fee payment, and also the labour walkout of THL. It is clear that the DKP has to advance the socialization into society about waste deportation timing and implement the penalty that is given to people who do not throw waste in the proper place. Further investigation can anticipate the distortion by diagnosing the problem of why the policy is still run, despite being a seemingly simple or an obviously complicated problem. The complexity problem level will need a different solution and also a different approach to get an answer.

This study is limited to the implementation in policy content and context viewpoint. Therefore, the nest study may focus on policy formulation, society participation in waste management or application of penalty for wasting in an inappropriate place.

\section{References}

Andon, P. (2012). Accounting-related research in PPPs/PFIs: Present contributions and future opportunities. Accounting, Auditing and Accountability Journal, 25(5), 876-924. doi: 10.1108/09513571211234286

Chen, Z., Daito, N., \& Gifford, J. L. (2016). Data review of transportation infrastructure public-private partnership: A meta-analysis. Transport Reviews, 36(2), 228-250. doi: 10.1080/01441647.2015.1076535

Cui, C., Liu, Y., Hope, A., \& Wang, J. (2018). Review of studies on the public-private partnerships (PPP) for infrastructure projects. International Journal of Project
Management, 36(5), 773-794. doi: 10.1016/j.ijproman.2018.03.004

De Castro E Silva Neto, D., Cruz, C. O., Rodrigues, F., \& Silva, P. (2016). Bibliometric analysis of PPP and PFI Literature: Overview of 25 years of research. Journal of Construction Engineering and Management, 142(10),1-8. doi: 10.1061/ (ASCE)CO.1943-7862.0001163

Ke, Y., Wang, S., Chan, A. P. C., \& Cheung, E. (2009). Research trend of public-private partnership in construction journals. Journal of Construction Engineering and Management, 135(10), 1076-1086. doi: 10.1061/ (ASCE)0733-9364(2009)135:10(1076)

Klijn, E. H. (2010). Public-private partnerships: Ueciphering meaning, message and phenomenon. International Handbook on Public-Private Partnerships, 68-80. doi: 10.4337/9781849804691.00011

Klijn, E. H., \& Koppenjan, J. (2016). The impact of contract characteristics on the performance of public-private partnerships (PPPs). Public Money and Management, 36(6), 455-462. doi: 10.1080/09540962.2016.1206756

Koppenjan, J. (2008). Public-private partnership and mega-projects. Decision-Making on Mega-Projects: Cost-Benefit Analysis, Planning and Innovation, (July), 189-214. doi: 10.4337/9781848440173.00017

Kurniawan, H. K. (2016). Studi deskriptif strategi public private partnership pengelolaan sampah di TPA Benowo Kota Surabaya. Jurnal Kebijakan dan Manajemen Publik, 4(2), 210-219.

Marsilio, M., Cappellaro, G., \& Cuccurullo, C. (2011). The intellectual structure of research into PPPS: A bibliometric analysis. Public Management Review, 13(6), 763-782. doi: 10.1080/14719037.2010.539112

Meidiana, C., \& Gamse, T. (2010). Development of waste management practices in Indonesia. European Journal of Scientific Research, 40(2), 199-210. 
Nahruddin, Z. (2016). Kemitraan publik-privat dalam pengelolaan sampah di TPA Tamangapa Kota Makassar. Government: Jurnal Ilmu Pemerintahan, 9(1), 11-20.

Sai, S., Bommareddy, R., Student, M. T., Pradesh, A., Dean-academics, A., \& Pradesh, A. (2017). Solid Waste Management Through Public-, 8(1), 263-272.

Setyawati. (2018). 1) , 2) , 2) 1). Journal of Public Policy and Management Review, 7(4), 227-237.

Sharma, M., Bindal, A., \& Cantt, S. D. C. A. (2014). Public-Private Partnership, (7), 1270-1274. Wang, L., Yan, D., Xiong, Y., \& Zhou, L. (2019). A review of the challenges and application of public-private partnership model in Chinese garbage disposal industry. Journal of Cleaner Production, 230, 219-229. doi: 10.1016/j.jclepro.2019.05.028

Yandra, A., Nasution, S. R., Harsini, H., \& Wekke, I. S. (2018). Mainstreaming Regional Budget (APBD): Issues and Challenges in Riau Province in 2015. Politik Indonesia: Indonesian Political Science Review, 3(1), 1. doi: 10.15294/jpi.v3i1.11510

Zhang, D. Q., Tan, S. K., \& Gersberg, R. M. (2010). Municipal solid waste management in China: Status, problems and challenges. Journal of Environmental Management, 91(8), 16231633. doi: 10.1016/j.jenvman.2010.03.012 